\title{
Vi skal tro på FN!
}

Af Frederikke Laursen

FN befinder sig ved en korsvej. Den liberale verdensorden, som vi har kendt den siden murens fald i 1989, er i konstant forandring og under massivt pres. USA som tovholder for den internationale retsorden og de globalt fastsatte regler trækker sig måske tilbage til en isolationistisk position. Begivenheder som Brexit, valget af Donald Trump som USA's præsident, et asiatisk alternativ til Verdensbanken er alle eksponenter for en verdensorden, hvor 'glokalisering' præger samarbejdet mellem stater og organisationer. Spørgsmålet er: hvilken opbakning kan FN forvente i en ny verdensorden, hvor medlemsstaterne lukker om sig selv?

Tendensen er både ny og uventet for langt de fleste kommentatorer, politikere og samfundseksperter, da disse i mange år har abonneret på teorien om, at internationale organisationer automatisk vokser i betydning og omfang - og ikke det modsatte. Hvilke udfordringer - og muligheder - står FN overfor i denne nye verdensorden? Og hvorfor skal vi stadig støtte op om FN?

Da FN blev oprettet i 1945, var det primære formål at skabe en organisation, der skulle sørge for, at man undgik en gentagelse af de to voldsomme verdenskrige. Dengang havde organisationen 51 medlemslande og et primært sikkerhedspolitisk formål. I dag, er der 193 medlemslande og 2 observatørstater, og FN's funktioner er blevet udvidet til at inkludere børnerettigheder (UNICEF), flygtninge (UNHCR), udvikling (UNDP) og sundhed (WHO) foruden en international straffedomstol (ICC). I dag er FN's fredsbevarende tropper til stede i 16 lande verden over, fra Haiti og Libanon til Mali, Sydsudan og Vestsahara.

Men de geopolitiske rammer, som FN opererer indenfor, har ændret sig markant fra dengang FN blev oprettet. Henry Kissinger, den tidligere amerikanske udenrigsminister, udtalte i 2014 at da Churchill, Stalin og Truman fastsatte de tyske besættelseszoner af Tyskland i 1945, var det den sidste betydningsfulde enighed mellem medlemsstaterne. Denne skepsis kan også tydeligt aflæses i den internationale verdensorden anno 2017. USA's overtrædelse af NATO-mandatet i Libyen i 2011, Ruslands annektering af Krim i 2014 og senest sikkerhedsrådets handlingslammelse i forbindelse med Syrien-krisen er alle eksempler på kollektive

Frederikke Laursen er stud.scient.pol ved Aarhus Universitet og pt. i praktik på den danske FN-mission i New York. Artiklen vandt tredjeprisen i Det Udenrigspolitiske Selskabs og Udenrigsministeriets artikelkonkurrence 
sikkerhedsudfordringer, som FN har stået overfor blot i løbet af det sidste årti.

Det store spørgsmål er derfor, om der er grund til at være optimistisk på FN's vegne. Svaret findes ved at se på de geopolitiske udfordringer og muligheder, som FN står overfor i en ny verdensorden. Set ud fra sikkerhedsrådets vanskeligheder i Syrien fremstår FN som en organisation med væsentlige svagheder. Men helikopterblikket over hele organisationen tegner et billede af et FN, der stadig står stærkt.

\section{Den nye styrmand}

Antonio Guterres blev på årets første dag svoret ind som FN's nye generalsekretær. Guterres overtog posten fra den sydkoreanske politiker Ban Ki Moon, der ifølge mange havde været mere sekretær end general. Men hvorfor er stillingen som den højst placerede diplomat overhovedet vigtig? Hvad kan han, ud over at agere som kransekagefigur for FN?

For det første kan generalsekretæren sætte spørgsmål på den internationale dagsorden og præge diskussionen. Det var fx tilfældet, da Kofi Annan introducerede det folkeretlige R2P-koncept (Responsibility to Protect; red.) i 2005, hvor der kom eksplicit fokus på verdenssamfundets ansvar for at beskytte befolkninger mod overgreb fra deres egneregeringer. For det andet kan generalsekretæren agere mægler mellem stormagterne (og i særdeleshed de fem faste medlemmer af FN's sikkerhedsråd), netop fordi han som styrmand for organisationen skal være upartisk. For det tredje har generalsekretæren en unik platform til at kommunikere FN's dagsorden og fungere som talerør til det resterende verdenssamfund.

Guterres har grundet sine 10 år ved UNHCR ifølge eget udsagn flygtningespørgsmålet højt på dagsordnen. Guterres brugte sin platform ved indvælgelsen til at opfordre til en multilateral vending mod mere respekt og tolerance. Han har desuden allerede kommenteret Trumps udmeldinger om indrejseforbud for muslimer og kaldt dem direkte destruktive og en hjælp for terrorgrupper såsom Islamisk Stat.

Der hersker dermed ingen tvivl om Guterres' dedikerede indsats i verdens flygtningekriser. Som formand for UNHCR indførte han det bredtfavnende udtryk 'people on the move' for at beskrive de krisesituationer, hvori FN's flygtningeindsats skulle gælde. Det indebar alt fra internt fordrevne til klimaflygtninge, hvilket også har affødt kritik af Guterres' indsats.

Men det mest bemærkelsesværdige ved valget af Guterres er hverken hans stærke udmeldinger om Trump eller hans brede definition af flygtninge; det er tværtimod måden hvorpå han blev valgt. For det første var processen mere åben, end det tidligere har været praksis, og for første gang i FN's 70-årige historie var der offentlige høringer med hver kandidat. For det andet trådte alle 15 medlemmer af sikkerhedsrådet $\mathrm{i}$ enighed frem med deres valg af kandidat flere uger før forventet. Mange eksperter havde ellers forventet, at Rusland ville nedlægge veto, fordi stormagten hellere ønskede en østeuropæisk kandidat til den diplomatiske toppost.

Alt imens man i de internationale medier malede USA og Rusland som modstående stormagter i en fasttømret proxy-krig i Syrien, formåede de i sikkerhedsrådet i New York hurtigt at blive enige om en ny generalsekretær. Guterres blev valgt ind med sikkerhedsrådet i ryggen, hvilket fint illustrerer en kærkommen opvisning af konsensus fra FN's side. Valget af en ny generalsekretær er derfor en 
sjælden mulighed for FN til både at udvise enighed på trods af mangfoldighed og understrege styrken af det internationale diplomati.

\section{Det svageste led}

Dog er alt ikke fryd og gammen mellem de tidligere konkurrerende stormagter. Krisen i Syrien er en af tidens største udfordringer for $\mathrm{FN}$-systemet, og den manglende konsensus sås i FN’s sikkerhedsråd, hvor Rusland i ledtog med Kina op til seks gange nedlagde veto mod alle resolutioner, der skulle standse blodsudgydelserne i Syrien. Resolutionerne var af varierende ambitionsniveau og inkluderede alt fra 'no-fly zoner' til reelle interventioner.

Selvom denne konflikt af gode grunde har præget dagsordenen og det internationale billede af FN's funktionalitet de seneste fem år, er det vigtigt at huske, at FN har utallige andre missioner, opgaver og forpligtelser ud over, hvad der afgøres af sikkerhedsrådet. Det er nemt at glemme, at sikkerhedsrådet blot udgør ét aspekt af FN's arbejde, fordi kriserne, der blusser op, af gode grunde kan være altoverskyggende. Dermed ikke sagt, at FN ikke har en væsentlig udfordring i form af manglende konsensus blandt stormagterne, fordi det blev tydeligt illustreret i Aleppo. Argumentet her er blot, at der ikke burde blive stillet spørgsmålstegn ved FN's grundlag, legitimitet og funktionalitet på grund af manglende konsensus i Syrien-krisen.

Man skal ikke glemme, at FN kun er så stærkt som enigheden af dets medlemmer. Dilemmaet for FN anno 2017 består derfor (igen) i at finde den knivskarpe balance mellem at beskytte befolkningsgrupper mod overgreb fra egen regering uden at trampe på landenes suverænitet. Hvis ikke USA havde ageret, som de gjorde i både Irak i 2003 og Libyen i 2011, så havde Rusland formentlig ikke holdt så hårdnakket på at bestytte Bashar al-Assads regimestabilitet. Modsat er Syrien stadig Ruslands eneste reelle allierede i Mellemøsten, hvorfor det er svært at klandre Vesten for ikke at træde ind og fremprovokere en direkte militærkonfrontation mellem Rusland og USA. Som sagt: FN er kun så stærk som det svageste led i sikkerhedsrådet.

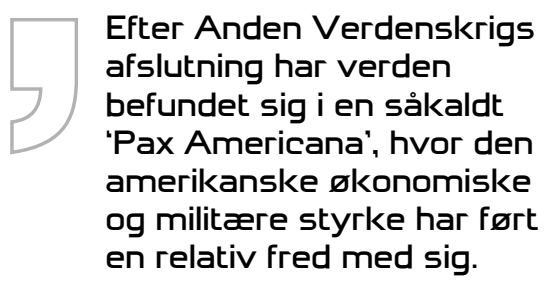

Mange eksperter har i kølvandet på Aleppo-krisen også påpeget muligheden for enten at udvide eller indskrænke vetoretten i sikkerhedsrådet. Grunden til, at man kun gav vetoret (og derfor større magt) til de heldige fem, var for at få dem til at tage ansvar. Men idéen om ansvar fortolkes forskelligt af medlemmerne af sikkerhedsrådet. For Rusland og Kina betyder ansvar, at suveræniteten og landegrænserne forsvares mod de såkaldte 'indgreb', som Vesten har været bannerfører for. For Storbritannien, Frankrig og USA har ansvaret betydet, at man skulle forsvare menneskerettighederne i de pågældende lande. En stor udfordring for FN er derfor at forene de divergerende fortolkninger af stormagtsansvaret.

\section{En stormagt på tilbagetog?}

Men hvem er stormagterne egentlig? Efter Anden Verdenskrigs afslutning har verden befundet sig i en såkaldt 'Pax Americana', 
hvor den amerikanske økonomiske og militære styrke har ført en relativ fred med sig. Men det er ved at ændre sig. Selvom de internationale institutioner, herunder FN, NATO og Bretton Woods-institutionerne (Verdensbanken, og den Internationale Valutafond), er drevet fremad på amerikansk initiativ, er der tiltagende bekymring for USA's rolle, når kalenderbladet har rundet 20. januar 2017.

Set med FN-briller er Donald Trumps mest bekymrende udmelding hans åbenlyse foragt over for de internationale institutioner. Parisaftalen om bekæmpelse af klimaforandringer, der betegnes som en af FN's største successer i mange år, har Trump allerede planer om at afmontere. Aftalen med Iran om afskaffelse af atomvåben, der anses for en multilateral diplomatisk sejr, skal ifølge Trump og hans stab afmonteres.

Derudover vil Trump rykke den amerikanske ambassade i Israel fra Tel Aviv til Jerusalem og derved signalere, at den strategiske by er israelsk territorium. Hvad man end måtte mene om indholdet af disse tiltag, så signaleres her en klar afstandtagen fra deltagelsen i og tilliden til de internationale institutioner, som Obama-administrationen var stor fortaler for.

Så hvor efterlades FN, hvis man ser et USA under Trump, hvor anti-institutionalisering er dagens ord?

Man kan kun gisne, om Trump rent faktisk vil gennemføre disse tiltag. Men hvis vi ser amerikansk tilbagetrækning, kan det diskuteres hvorvidt FN kan køre ufortrødent videre uden USA's tydelige lederskab.

På den ene side er USA blot en enkelt spiller i FN-systemet. Men hvis USA påtager sig en ny rolle i de internationale institutioner med en isolationistisk udenrigspolitik, kan FN's legitimitet svækkes ved tabet af en vigtig fortaler. På den anden side har FN-systemet formået at cementere sig i det internationale samfund i en sådan grad, at selv ikke amerikansk skepsis kan rokke ved den grundlæggende mission og udførsel.

USA var selvfølgelig primus motor på oprettelsen af størstedelen af de internationale institutioner (herunder FN), men der er kommet nye, geopolitiske boller på suppen. Fremkomsten af BRICS-landene er et tydeligt resultat af den globaliseringstendens, der er vundet frem de sidste 10-15 år. Både Brasilien og Kina har bragt nye initiativer på bordet ved FN's generalforsamling om R2P-princippet, som er blevet afvist af de vestlige stater. Disse initiativer bør i stedet imødekommes, vurderes og endda integreres i FN's institutionelle ramme.

Hvis det ikke lykkedes, vil disse vækst$ø$ konomier en dag danne alternative institutioner, hvor deres stemmer høres. For at FN kan vedligeholde slagkraften i en verdensorden med mindre amerikansk tilstedeværelse, kræves derfor to ting. For det første skal andre nationer træde til og kollektivt tage ansvar for de internationale organisationer - og lære af USA’s hårdt tjente udenrigspolitiske erfaringer. For det andet skal denne ansvarspådragelse accepteres og bydes velkommen med åbne arme af både sikkerhedsrådet og generalforsamlingen.

\section{Start med regionalt ejerskab}

En af de største udfordringer for FN i den nye verdensorden er den manglende konsensus om konfliktløsning. Det kan imødekommes ved at inddrage de regionale organisationer. Den Afrikanske Union, ASEAN, den Arabiske Liga og ECOWAS (den økonomiske sammenslutning af østafrikanske stater) er eksempler på organi- 
sationer, der har spillet store roller i konfliktløsning i Mellemøsten og Afrika.

Disse organisationer kan tilføre FN's operationer afgørende legitimitet, netop fordi en invitation til intervention herfra giver FN et tydeligt mandat og øger multilateralismens diplomatiske styrke. Det kan illustrere over for medlemmerne af FN's sikkerhedsråd, at en intervention (humanitær eller ej) er ønsket og værdsat af de lokale regeringer og magthavere.

\section{Det er FN's globale ræk- kevidde og universelle medlemskab, der gør organisationen unik, og dette ændres ikke i ny og multipolær verdensorden.}

Hvor positivt det end måtte lyde, er regionalt ejerskab over konflikter ikke en tilstrækkelig betingelse for succes. Jeg argumenter for, at regionalt ejerskab ikke kan eksistere i et vakuum uden tilstedeværelsen af stormagterne, hvilket er en stor udfordring for organisationernes legitimitet og slagkraft.

Fx var interventionen i Libyen i 2011 både en idé født af den Arabiske Liga og et initiativ, som organisationen stod inde for. Det var centralt for Resolution 1973's gennemførsel (der muliggjorde interventionen), at formålet var humanitært og ikke indebar et regimeskifte. Men Muammar Gaddafi blev alligevel smidt af tronen, hvilket især Rusland var dybt utilfredse med.

Mange mener derfor også, at Ruslands mistillid til Vesten (især USA) blev fremskyndet af Libyen-konflikten på trods af den regionale organisations anerkendende nik. Libyens efterfølgende udvikling har langt fra været positiv, da landet stadig er plaget af terrorisme, økonomiske proble- mer, politisk uro mm. Denne case illustrerer derfor, at stormagtsinteresser kan filtreres gennem regionale organisationer, hvorfor FN spiller en afgørende rolle i at kultivere og samarbejde med dem. Kun på den måde kan organisationerne lære at tage ansvar - fra finansieringen af tropperne til den efterfølgende politiske plan. Det er derfor afgørende, at stormagterne begynder at sætte deres lid til disse organisationer, der har udvist et brændende ønske om konfliktløsning.

Et eksempel på konsensusskabelse mellem de 'nye' og 'gamle' stormagter og de regionale organisationer er i den afrikanske stat Mali. Da den første resolution om konfliktløsningen enstemmigt blev gennemført i sikkerhedsrådet i 2012, var alle BRICS-landene på nær Brasilien i panelet, og efterfølgende har samtlige af Malis nabostater både bidraget med tropper og logistik. Både ECOWAS og den Afrikanske Union var med i beslutnings- og implementeringsprocessen fra starten, hvilket er en af læresætningerne fra konflikten. Det regionale ejerskab fordrer dog også regionalt ansvar, og fordi disse organisationer er relativt nye, er FN's vejledende rolle mindst lige så vigtig som altid.

\section{Rigtige reformer}

Der er adskillige grunde til at tro på, at FN består prøven i en ny verdensorden men det kræver reformer. Center for Militære studier i København udgav for nylig en rapport, der argumenterede, at hvis FN skal forblive relevant, skal organisationen gennemføre både diplomatiske og militære reformer.

Det fremhæves, at FN i højere grad bør fokusere på konfliktforebyggelse, individer og partnerskaber. Dog er ingen af disse reformforslag nye; tværtimod nævnes de alle i FN's Charter fra 1945. Det nye 
initiativ består $\mathrm{i}$ at dyrke dem intensivt, og at medlemsstaterne skal have tillid til, at disse redskaber er de rigtige.

Det betyder ikke, at man ikke skal diskutere FN's rolle, eller at man ikke skal sætte spørgsmålstegn ved reformer af $\mathrm{fx}$ vetoretten. Men at kritisere FN's fundament og overlevelsesevne blot fordi USA trækker sig tilbage, og det internationale samfund er mere splittet end før, er forhastet. Jeg argumenterer her for, at USA naturligvis havde en vigtig rolle i at iværksætte og videreudvikle FN, men for at undgå at FN kolliderer med den nye verdensordenes realiteter, skal andre medlemsstater også tildeles tillid og tage ansvar.

Det er FN's globale rækkevidde og universelle medlemskab, der gør organisationen unik, og dette ændres ikke i ny og multipolær verdensorden.

\section{Nye forhandlingspartnere}

Men FN skal - ligesom alle andre internationale organer - tilpasse sig ændringerne i en geopolitisk kontekst. Det betyder også, at man i højere grad skal sætte sin lid til nye aktører, end man er vant til. Det eksemplificeres ved de FN-støttede forhandlinger i Astana, Kasakhstan i slutningen af januar 2017, hvor Rusland og Tyrkiet har stablet en fredsforhandling på benene mellem Assad-regeringen og oppositionen. USA er blevet udelukket fra forhandlingerne, og det er derfor Rusland og Tyrkiet, der styrer fredsmæglingen.

Her ses det tydeligt, at der allerede er centrale internationale konflikter, hvor USA ikke længere er kaptajn på den diplomatiske skude. Om Rusland har stået i front for processen for at bevise sit regionale og internationale ansvar eller om det er en bevidst modbalancering mod USA's diplomatiske dominans, vil tiden vise.
Uanset motivet har Rusland smidt sine kort på bordet og har nu diplomatisk kapital på spil.

Det er dog ikke kun BRICS-landene og de andre økonomisk stærke nationer, men også de regionale organisationer, som det internationale samfund skal se imod. De har væsentlige fordele i form af geografisk nærhed og indgående kendskab til regionens politiske og sociale sammensætning. Vi skal derfor høre efter, hvad de regionale organisationer vil og kan, så FN ikke tvinges til en reaktionær adfærd, som i værste fald kan føre til udfald som i Rwanda og Aleppo.

\section{Begrundet optimisme}

Så opvejes FN's udfordringer af mulighederne? I denne artikel er svaret et rungende ja. En oplagt årsag til at være optimistisk på FN's vegne er udviklingsagendaen. FN's 2030-bæredygtighedsmål er langt mere omfattende end de 2015mål, som de erstattede, og for første gang har målene universel validitet og gælder for både udviklingslande, vækstøkonomier og ilande.

De nye mål er desuden uovertrufne i den måde, hvorpå de kombinerer de økonomiske, sociale og miljømæssige dimensioner af bæredygtig udvikling. Ambitionsniveauet for disse mål er højt, og derfor kræves der også mere af medlemsstaterne. Men for første gang er ansvaret fordelt på alle nationer i en grad, der ikke hidtil er set i det internationale system. Det er et skridt i den rigtige retning og viser endnu en mulighed for, hvordan FN kan reformere sig og overleve i en ny og anderledes verdensorden.

I et år hvor FN’s legitimitet i kølvandet på Syrien-krisen er blevet betvivlet, er det derfor vigtigt at anskue FN i et bredere perspektiv. Bæredygtighedsmålene, 
Ingen kender verdensordenen om 5, 10 eller 15 år, men netop derfor skal vi have tillid til de institutioner, der binder os sammen, fremfor at fokusere på begivenheder der kan rive os fra hinanden.

det hurtige valg af generalsekretær, Mali-konfliktens konsensus, villigheden til reformation og inddragelse af nye forhandlingspartnere er alle eksempler på den diplomatiske styrke, som FN er fyrtårn for.

FN muliggør, at det internationale samfund kan overkomme udfordringer kollektivt. Netop fordi organisationen står ved en korsvej, er det afgørende, at vi (Danmark såvel som resten af det internationale system) sætter vores lid til FN. Hvis vi ikke tror på det kollektive ansvar og mulighederne for at løse internationale konflikter i fælleskab, smuldrer fællesskabet for alvor.

På talerstolen ved FN's generalforsamling i september 2016 formulerede præsi- dent Barack Obama også denne tilgang: "We can choose to press forward with a better model of cooperation and integration. Or we can retreat into a world sharply divided, and ultimately in conflict, along age-old lines of nation and tribe and race and religion. I want to suggest to you today that we must go forward, and not backward".

Ingen kender verdensordenen om 5, 10 eller 15 år, men netop derfor skal vi have tillid til de institutioner, der binder os sammen, fremfor at fokusere på begivenheder, der kan rive os fra hinanden. 